\title{
FRAGMENTOS DE HISTORIA DE LA LENGUA (H. 943-H. 1500)
}

\author{
Francisco Abad Nebot \\ UNED. Madrid \\ fabad@flog.uned.es
}

\section{RESUMEN}

Hablamos de historia de la lengua española en varios momentos (entre 943-1500).

Palabras Clave: Dialecto castellano; larga duración; cambio lingüístico; Ramón Menéndez Pidal; Eugenio Coseriu.

\section{RESUMÉE}

Nous parlons d'histoire de la langue espagnole dans plusieurs moments (entre 9431500).

Mots-CLEFs: Dialecte castillan; longue durée; changement linguistique; Ramón Menéndez Pidal; Eugenio Coseriu.

EL CONCEPTO DE «LENGUA HISTÓRICA»

El sociolingüista W. L. Stewart ha manifestado que las lenguas poseen un atributo de historicidad, esto es, que cada una es «el resultado de un proceso de desarrollo a través del uso», y ciertamente una lengua es un resultado de su empleo, de su trayectoria.

Toda lengua consiste en una técnica, pero la técnica que corresponde a una lengua histórica -mantiene Coseriu (1981, 302-315) no es nunca perfectamente homogénea: 
antes bien de ordinario «es un conjunto bastante complejo de tradiciones lingüísticas históricamente conexas pero diferentes y sólo en parte concordantes», es decir, se trata de un continuo idiomático y de una complejidad interior de formas a veces diversificadas.

Las diferencias internas que se presentan en una lengua aclara Coseriu que son las diatópicas, las diastráticas [ 'las determinadas por el diverso nivel sociocultural de los hablantes»], y las diafásicas -las diferencias llamadas «estilísticas» o de modalidad expresiva o registro-: resulta así que «una lengua histórica no es nunca un solo sistema lingüístico sino un diasistema, un conjunto más o menos complejo de «dialectos», «niveles» y "estilos de lengua"». En verdad las lenguas son continuos o diasistemas, y también se las ha caracterizado en tanto sistemas de sistemas, lo que viene a equivaler a diasistemas: llevan en ellas una suma de diferenciaciones interiores de las que el hablante puede tener conciencia o no, pero que se dan objetivamente.

Estamos en el caso de cualquier lengua histórica ante un verdadero complejo «dialectal» interior que contiene varios sistemas expresivos; a cada uno de ellos los denomina nuestro autor -según vemos- lengua funcional, que es «una técnica lingüística enteramente determinada (o sea, unitaria y homogénea) en los tres sentidos en cuestión -un solo dialecto en un solo nivel y en un estilo único de lengua, en otras palabras: una lengua sintópica, sinstrática y sinfásica». Pero es sólo una de estas lenguas o códigos funcionales la que puede describirse cada vez: la lengua histórica lleva en sí un complejo «dialectal»-vemos- de lenguas funcionales y como tal no puede hablarse nunca (ya que ninguno de los hablantes tiene interiorizado el conjunto de todas las lenguas funcionales de que consta un idioma histórico, y expresivamente tampoco acaso le hará falta nunca); tal idioma no se habla nunca y no cabe describirla indiscriminadamente, sino distinguiendo lo que son códigos funcionales diferentes. Es además un error denominar -según a veces se hace- «lengua funcional» al hablar ordinario, a la lengua común.

O sea, la configuración interna de una lengua es resultado de su historia, pero cabe analizarla según sólo tal configuración interior, o teniendo en cuenta además la historia general que ha podido incidir en el idioma de que se trate.

Desde luego -en efecto- el análisis de cualquier aspecto de una lengua histórica puede hacerse atendiendo sólo a los que se han denominado «factores internos», o atendiendo a la vez a esos factores internos y asimismo a los externos: Kurt Baldinger (1977; asimismo 1985, 249-250) formuló en particular que «tanto en la sincronía como en la diacronía hay que distinguir entre ahistórico (es decir, sin consideración del hablante en una situación histórica determinada) e histórico (es decir, con consideración del hablante en una situación histórica determinada)»; esto supone que todo estudio de un aspecto de cualquier lengua histórica puede atender a los factores externos -en lo que ellos resulten pertinentes-, o no. Cada idioma se va constituyendo cambiantemente a lo largo de una historia, pero nosotros podemos describirlo en tanto sólo un instrumento formal, o bien con atención al conjunto de lo histórico general que sin duda ha incidido en él.

De todas maneras y según queda visto, considerada en sí misma una lengua consiste en cada momento de su historia o diacronía en el resultado de una trayectoria de desarrollo a través de su uso: cada idioma posee funcionalidad y pasado, se va constituyendo con el tiempo. 


\section{LENGUA COMÚN; LENGUAS DIALECTALES Y LOCALES; LENGUA ARTÍSTICA}

Que una lengua o idioma (una «lengua histórica») presenta por su misma consistencia diferentes variedades es algo sobre lo que se vio llamado también a escribir -en unas páginas suyas no siempre atendidas- Ramón Menéndez Pidal.

Pidal conocía por experiencias personales y por análisis intelectuales las lenguas dialectales y las hablas locales, operaba de manera implícita con la diferenciación entre estilística de la lengua y estilística del habla establecida entre nosotros por Amado Alonso, etc., y expuso de esta manera instructivamente que

se distingue una lengua común, la de ámbito más extenso, la más general, a diferencia de las lenguas dialectales, que viven dentro del territorio de la lengua común y emplean formas fonéticas, morfológicas y sintácticas diversas de las comunes, aunque afines a ellas. Hay también lenguas locales o provinciales, que simplemente usan algunos vocablos de uso local y acaso una pronunciación algo distinta de la común (2005, II, 17).

No es fácil encontrar en la bibliografía unas líneas breves que caractericen con tanta claridad las varias clases de lengua como estas que acabamos de recoger; pero a su vez don Ramón sabe que en un mismo ámbito geográfico se dan también agrupaciones sociolectales de hablantes: estamos ante «la lengua de una clase social» o dialectos sociales; las jergas, etc. (Ibid.).

La lengua común y las que respecto de ella resultan más particulares se suman entre sí para el logro del acierto expresivo: don Ramón apunta algo bien lógico, que la lengua común da al hablante recursos expresivos de alto valor, y que los aciertos de eficacia de las lenguas particulares pueden pasar a ese lenguaje común; los hablantes cultos e ilustrados -venía a pensar el autor- escogen las formas y nivelan o reacomodan un habla que tiende a ser modélica: «La lengua común, formada mediante la exclusión o la parcial asimilación de los particularismos, se elabora en la conversación, en los negocios, en la literatura, por la selección de hablantes que viven las actividades superiores de la comunidad y participan de la más alta cultura» (2005, II, 18).

Hay casos en que la lengua escrita literaria se identifica con la dialectal o local, pero en cuanto escrito-literaria consiste en un arte, esto es, en un artificio: «aunque sea la [lengua] dialectal (Juan del Encina, Gabriel y Galán, etc.) o la local (Pereda, Güiraldes, etc.) siempre se distingue de la hablada por el artificio y mayor compostura» (Ibid., 20).

Ya queda indicado cómo Menéndez Pidal tenía presente la distinción entre estilística de la lengua y estilística de las hablas (literarias), y por eso puede manifestar así:

La lengua literaria [...] es más activa y más libre en la creación estilística individual, si bien es más respetuosa en la parte tradicional del idioma, en su fonética, morfología y sintaxis; es más renovadora que la lengua cotidiana en la parte de creación subjetiva, si bien es por lo común más conservadora en la parte hereditaria, en lo supraindividual, pues se instruye en la lectura de los autores del pasado [...]. La parte tradicional o supraindividual del idioma se modela y evoluciona por obra de la estilística colectiva, mientras la parte de expresividad personal evoluciona por influjo de los literatos (Ibid., 22).

Lo estilístico colectivo se encuentra gramaticalizado, y por eso es supraindividual; las innovaciones literarias son más privativas de algún o algunos escritores, aunque pueden generalizarse si unos autores repiten los modos de otros. El hablar literario -no 
obstante- no resulta siempre tan respetuoso con la morfología y la sintaxis tradicionales como parece creer Menéndez Pidal: fácilmente se vienen a la memoria autores que innovan en la formación de palabras, en algunos usos de sintaxis.

\section{HistoriogRAFÍA, IDEOLOGÍA Y POLÍTICA: LA CELEBRACIÓN DEL MILENARIO DE CASTILLA}

A los inicios del franquismo, en años de cerrada conciencia nacionalista y centralista, se celebró por el Régimen el denominado milenario de Castilla, dado que -interpretamos nosotros- en 943 ocurrió la rebelión de Fernán González contra Ramiro II; de manera puramente personal redactaron páginas entonces lo mismo Menéndez Pidal que Sánchez Albornoz, ya que eran los máximos especialistas en historia de la Castilla altomedieval. No hace falta insistir en que el uno y el otro maestro nunca fueron franquistas sino más bien lo contrario, y que fue su dedicación de antes de la guerra a la historia altomedieval y a la historia castellana específicamente lo que les hizo sentir la necesidad interior de expresarse; la visión historiográfica de ambos es romántico-nacionalista de lo castellano -pues así lo era la historiografía del «Centro de Estudios Históricos: también la de Américo Castro, en parte asimismo la de Luis García de Valdeavellano, etc.-, pero ambos (llevado ante los tribunales don Ramón por las que se estimaban sus responsabilidades políticas; en el exilio don Claudio) resultaban ajenos al mundo oficial que organizó estas conmemoraciones. Según bien señala el medievalista por igual relevante Miguel Ángel Ladero en referencia a don Ramón, «los principios éticos e intelectuales liberales [...] eran la médula misma de sus convicciones y actitudes» (Ladero 1998, 291).

Menéndez Pidal hizo en la ocasión un escrito luego bien conocido: el rotulado «Carácter originario de Castilla», fórmula en la que la voz «originario» significa efectivamente lo que dice el $D R A E$, 'que da origen a algo', pero que quizá su autor contaminó con el significado asimismo de 'original'. Castilla -enseña don Ramón- era un país nuevo cuyo nombre se aparecía como un neologismo para Alfonso III: «Vardulies qui nunc vocitatur Castellae»; se trataba de los castillos que en el siglo IX defienden Pancorbo, y de los castillos que en el siglo siguiente protegen la nueva frontera de la línea del Duero (vid. para todo esto Menéndez Pidal, 1943).

La idea pidalina es la de que Castilla surge en la España cristiana en tanto una fuerza innovadora, según recogerá y argumentará también Sánchez Albornoz. Singularidad castellana fue la de la literatura, a saber:

Esa mayor actividad literaria que desde la época de Alfonso el Sabio desplegó Castilla en comparación con todos los otros países peninsulares, puede también entreverse en la época de orígenes. [...] Sólo Castilla cultivó una nueva manera de historia, obra de juglares que hacían sus relatos en lengua romance, destinados al común de las gentes ignorantes del latín a quienes referían en forma popular, poética y cantada, los sucesos impresionantes del presente y del pasado; género épicopopular desconocido a la tradición latinoeclesiástica, pero no a la gótica.

En el hablar, los castellanos pronunciaban la $j$ fricativa (mujer frente a muller) y la $c h$ en vez de $t$ (muito); perdían dos consonantes iniciales, la $g$ y la $f$ (enero, hacer); usaban ya las formas diptongadas ue y ie. Castilla -al decir de don Ramón- posee una norma de habla claramente preferida, y ocurrirá luego la expansión de tal manera idiomática: «Entre los siglos XII y XV todos esos rasgos primitivos castellanos se propagan 
por el occidente leonés y por el oriente aragonés, y se implanta[n] en el sur en vez de los dialectos mozárabes». Nuestro autor entiende que se produce una nueva unidad idiomática peninsular castellanizante -luego de la relativa uniformidad lingüística de los tiempos visigóticos- otra vez desde la Baja Edad Media, y esa nivelación se alcanzó como efecto de la «cuña» del hablar castellano que penetra de Norte a Sur peninsular hasta el mar; esta imagen de una acción idiomática niveladora y uniformadora en forma de cuña (y luego más bien en forma de abanico) se atribuye siempre a don Ramón, pero en verdad ya la había empleado antes Unamuno a fines del Ochocientos; luego la han repetido muchos filólogos, entre ellos Antonio Alatorre (1989, 97; vid. Penny 1995).

Otra vez trató de las innovaciones castellanas don Ramón al prologar-como él hacía siempre- un tomo (el VI) de su Historia de España en Espasa-Calpe; el castellanismo ideológico de don Ramón le hacía gustoso este asunto de las peculiaridades del idioma patrimonial en referencia a las otras variedades lingüísticas peninsulares, y así le dedicó también un capítulo de su Historia de la lengua española. En este caso insiste en el carácter innovador y original que tiene todo lo castellano, y expone en una recapitulación esencial:

El romance que se hablaba en el reino astur-leonés [...] y en el reino navarro-aragonés [...] ofrecía muchos rasgos comunes [...] procedentes sin duda de la lengua oficial y cortesana [ toledana], lengua que ahora continuaban los hablantes en aljamía [ 'en mozárabe»] de al-Andalus [...]. De esa relativa unidad difería bastante Castilla, apareciendo como una cuña hincada en la parte alta de ese núcleo toledano-aragonés que ocupa el centro de la Península (Menéndez Pidal 2005, I, 363 y ss. para esto y lo que sigue).

El castellano se distingue en efecto por rasgos bien sabidos después de la obra del maestro entre los que se encuentran

-«no se dejó penetrar por las innovaciones propias de ese romance [visigótico] toledano»: Tú yes, Él ye, lluna, uello, les cases

-se pierde la $f$ -

- «la solución tan difundida del grupo CT $>y t[\ldots]$ progresa en Castilla hasta palatalizar la t, llegando a la palatal africada sorda [...] que hoy escribimos ch»

-la palatalización de los grupos latinos $\mathrm{LY}, \mathrm{C} \gg \mathrm{L}, \mathrm{G} \gg \mathrm{L}$ llega a la fricativa o africada $j$

-la pérdida de G- J- iniciales ante E o I inacentuada tardó en hacerse regular

-el castellano carece de la diptongación de $o$ y e tónicas breves ante yod, más común en las lenguas romances que la diptongación incondicionada. Etc. (cfr. además M. Pidal, 1943, 27-32).

Pero además de la objetividad cierta de unos rasgos lingüísticos que caracterizan idiomáticamente al dialecto castellano, Menéndez Pidal no deja de expresar su concepción historiográfica castellanista al hacer exposición de los caracteres con que Castilla aparece en la historia (lo comenta en concreto García Isasti, 443-447).

Con ocasión del mismo milenario castellano Sánchez Albornoz escribió con emoción y con belleza literaria acerca de los «Orígenes de Castilla», y al hacer referencia a las campañas de ataque musulmanas, recuerda el alzarse de fortalezas: «Así aquellas altas tierras, antaño de autrigones y de cántabros, aquellas tierras entre cuyas montañas corre el Ebro en sus primeros pasos hacia el Mediterráneo, se poblaron de torres y cas- 
tillos en la primera mitad del siglo IX, y la comarca que les vio erguirse [...] empezó a llamarse, y con razón, Castilla» (Sánchez Albornoz,1943, 281); debe saberse que Autrigonia era llamada en la segunda mitad del siglo viII Vardulia.

El particularismo castellano -proclama Sánchez Albornoz en parte con su maestro Menéndez Pidal- hizo que estas comarcas fuesen innovadoras en el lenguaje, en el derecho, en los cantares de gesta, en la vida político-social con las behetrías o señoríos libres y la clase de los caballeros villanos $(1943,295)$.

La presente interpretación quedó refundida en la obra magna albornociana España, un enigma histórico, y entonces nuestro autor nota de nuevo el carácter innovador de Castilla en el idioma, en el derecho, en la literatura, etc., así como -añade ahora- en la vida monástica, al aceptar pronto la regla benedictina reformada por Smaragdo (1983, II, 387-404). Y aún en alguna ocasión más -que recordemos- se hizo eco el autor de esta visión acerca de las novedades históricas que aportaba Castilla $(1979,25)$.

\section{CRistianos, Musulmanes y Judíos}

En su libro - de relieve en la historia intelectual española de la posguerra- España en su historia (1948), Américo Castro postuló una impronta hebraica determinante en el nacimiento de la prosa en lengua castellana. Dedica más de un epígrafe de su libro a Alfonso $\mathrm{X}$ y los judíos, y mantiene que el judío debía de tener poco interés por la lengua latina que era la del Occidente cristiano de civilización unitaria: «la lengua por excelencia era para él el hebreo; luego el árabe como expresión de la cultura más valiosa; desde el siglo XIII, el castellano se les impuso como el idioma de su única patria posible». La lengua castellana no se forjó sino en esta centuria del Doscientos por encima -por ej.- del dialecto leonés, y esto supone un dato fundamental: el de su constitución como tal lengua, aunque asimismo fundamental en su trayectoria resultaron por ej. los hechos de 1492. Américo Castro -de acuerdo con el espíritu todo de la interpretación que hizo de la historia de España-, enfatiza este dato del surgir de la prosa castellana en el que el papel más definitorio lo tuvieron los hebreos peninsulares; sus líneas son muy bellas:

Hay que hacer algún esfuerzo para entender el acontecimiento más decisivo en la historia de la lengua española. No basta con decir que el rey lo quiso y fué, pues Alfonso X no se habría arrojado a ordenar la redacción en castellano de la historia del mundo, de la ciencia astronómica y de la enciclopedia jurídica de su tiempo, de no haber tenido junto a sí un grupo de sabios que le descubriera la ciencia encerrada en los libros arábigos y latinos, y mostrara al mismo tiempo más interés en cultivar el romance que el latín (A. Castro 1948, 486 y 493-494).

Estamos ante unas palabras bellas pero acaso no exactas: se manifestó acerca de ellas Menéndez Pidal y luego lo han hecho más autores. Don Ramón estima ciertamente el «hermoso libro» de su discípulo, y plantea que la hipótesis que él había expuesto debe contrastarse en el conjunto de los hechos, y en ese sentido subraya que era tendencia natural de las lenguas vernáculas el llegar a una prosa para competir con el latín en tanto instrumento de ilustración y enseñanza: existía -insiste- un general deseo de secularizar las tareas intelectuales (1968a, 52-53). 
En particular don Ramón hizo referencia a dos contemporáneos: el rey de Castilla y R. Bacon:

Alfonso X no podía menos de sentir esa general tendencia secularizadora de la cultura. Añádase que un contemporáneo [, el franciscano] Roger Bacon, expresaba el descrédito que por entonces pesaba sobre la lengua latina como lengua científica: lo escrito en ella valía muy poco, según el doctor mirabilis, y había que acudir a las lucubraciones redactadas en otras lenguas, in linguis alienis, por sabios paganos y musulmanes.

Así las cosas, cabía incorporar el habla materna en tanto vehículo de la ciencia. Pero además ocurría otro hecho al que ya hemos visto hacer alusión a Menéndez Pidal: el atractivo del árabe como lengua viva y a la vez escrita, que estaba usada en los distintos saberes. En definitiva sucedió -es la interpretación pidalina- que «la Escuela de Traductores en latín trajo como consecuencia natural la Escuela de Traductores en romance» (Ibid., 53; vid. Sánchez Albornoz 1981, 183-206; etc.).

Más en nuestros días el historiador del Derecho José Manuel Pérez Prendes argumenta que la tesis de la impronta judaica en el nacer de la prosa de Castilla parece innecesaria, y a ella se le pueden objetar dos hechos: que basta para explicar los hechos la tendencia europea que queda aludida hacia la secularización de la cultura; y que «los asesores hebreos del monarca castellano trabajaban en conjunto con sacerdotes cristianos» (1984, 44; vid. también F. Márquez Villanueva, 1994, esp. 29-42).

\section{El uso del Castellano y el pensamiento político de Alfonso X}

Pero aún se han dado -y adecuadamente- otras interpretaciones del empleo de la lengua castellana escrita y formal en la segunda mitad del Doscientos, y así nos ha de importar el lugar de Alfonso X en la historia del pensamiento político español, pues es ese pensamiento político el que por una relación de coherencia ayuda asimismo a entender que Alfonso impulsase el empleo del vernáculo como registro culto; el único autor-que sepamos- que lo ha planteado de esta forma es José Antonio Maravall, quien de manera general postula interpretaciones no casticistas de la historia de España, sino que postula que esa historia se entienda en el todo del Occidente europeo. De manera alternativa -aunque manifestada de manera implícita- a la de Américo Castro, Maravall sentó esta tesis fundamental:

La imagen de nuestra historia se aparta, sí, de la de cualquier otro país en el conjunto europeo, como la de cada uno de estos respecto a los demás. No hay una Edad Media uniforme [...]. La Edad Media española es un aspecto de la cultura medieval de Europa y una matización de su cultura (1983b, 435).

En el presente contexto interpretativo cabe entender que el monarca castellano representa un momento en la historia del pensamiento político europeo: el paso del ya antiguo régimen feudal «al régimen corporativo de base territorial», al régimen organizativo territorial de la ordenación en reinos; estamos ante una nueva forma política «no determinada estructuralmente por las relaciones de beneficio-vasallaje, sino por los vínculos nacidos de la común pertenencia a alguno de los «corpora», que son los reinos». Tal concepción política del territorio -territorio juntamente extenso y vinculado a la historia y la vida de una 
comunidad- «es lo más característico» del pensamiento político alfonsí (Maravall, 1983a, 99 y 101). La lengua castellana -en nuestro caso- es el idioma de la comunidad territorial propia, y en tal supuesto el monarca la favorece; desde luego no todo el reino de Castilla tenía como hablar vernáculo el castellano, pero sí era el de mayor población: hacia 1300 poco más tarde de Alfonso- Castilla y Portugal tenían 4 millones de habitantes, la Corona de Aragón 1 millón, y Navarra 100.000 de esos habitantes (Pérez Moreda, 1988, 368); otra estimación calcula para la Corona de Castilla hacia el mismo 1300 unos 5.000.000 de habitantes (Riu, 1984, 86b), pero lo que importa ahora es su -comparativamente- mayor población y así un número más alto de castellanohablantes.

El monarca castellano está en la idea de que todo reino «es un cuerpo [«una organización»] sustantivo que postula su propio derecho», y de este modo los derechos y deberes se refieren al grupo territorial (Maravall, 1983a, 116 y 127). Y en este mismo orden de ideas y concepciones políticas entra asimismo la labor historiográfica promovida por el rey juntamente con la lengua castellana:

La conversión del pueblo en sujeto historiográfico es una de las grandes innovaciones en la obra incomparable del rey Alfonso. La aparición del pueblo como sujeto activo y a la vez destinatario de la Historia, provoca en ésta [la innovación de que se haga relato] de lo acontecido a una comunidad (Ibid., 142).

Contamos con esta innovación en la historiografía alfonsí, y además con el uso en ella del idioma vernáculo de la comunidad política en tanto registro literario y culto: si la Historia se escribe acerca del pasado de un pueblo, «es natural -razona J. A. Maravallque se escriba en su lengua común [, y puesto que el Derecho es Derecho] de un pueblo para darle concordia y unidad y regir su vida en comunidad, debe también ponerse en la lengua que ese pueblo habla» (1983b, 143)

Las Partidas, las Historias de España y del mundo, se escriben en la que ya es lengua castellana, y la relevancia que le otorga don Alfonso responde a la estimación de que «lo hace con conciencia de servirse, en favor de la comunidad, de una lengua que a ésta pertenece» (Ibid., 144).

Tenemos así que una misma doctrina del orden político lleva a transformar las ideas de territorio, Derecho, Historia, empleo de un código lingüístico u otro, ...

\section{EL PROCESO IDIOMÁTICO CASTELLANO EN EL MARCO DE LA LA FORMACIÓN GEOHISTÓRICA DE ESPAÑA}

El ya aludido medievalista Miguel Ángel Ladero, ha subrayado bien que las centurias que van de hacia 1050 hasta hacia 1300, constituyen temporalmente la matriz común de la que derivará la España posterior que llega a nuestros días, y plantea así cómo

la España que hoy conocemos y vivimos se hizo en aquellos dos siglos y medio, en su territorio, en sus regiones -sólo Granada y Canarias son algo más recientes-, en su forma geo-histórica. Ningún otro período de la historia española puede parangonarse a aquél en estos aspectos. [... Hay además otros hechos] -sociales, políticos, culturales- que hacen de la plena Edad Media el tiempo en el que nacieron o maduraron verdaderamente la inmensa mayor parte de los aspectos que componen la realidad histórica originaria de la España actual. Lo anterior es casi siempre pre-historia de España (1998, 34-35). 
Al termino de tales siglos «se habían consolidado una sociedad y una cultura nuevas dentro del modelo europeo general, [aunque] con peculiaridades tanto internas como con respecto a otras regiones del Occidente», según estimaba asimismo el historiador Maravall; ocurría también en el entorno del 1300 «un concepto ya muy elaborado sobre la existencia histórico-cultural de España que permitiría en el futuro [...] imaginar y justificar proyectos de convergencia política» $(1998,68-69)$.

Si se traslada o extrapola este dato del relieve de 1050/1300 a lo lingǘstico que nos importa, podría decirse que es también en esas centurias cuando va progresando hacia su fin la época denominada por Menéndez Pidal de orígenes próximos de la lengua -aunque él la detiene en 1100-, y cuando ocurre la consolidación del castellano hasta hacerse en la segunda mitad del Doscientos un idioma para todos los usos (con algunas excepciones: la filosofía, o la medicina, etc.); antes del 1200 cabría hablar sin falta a la realidad de los hechos de una cierta pre-historia de la lengua castellana, que sólo era entonces lengua vernácula y de la literatura en verso, no un idioma generalizado en la mayor parte de los empleos escritos.

\section{HACIA EL AÑO 92: I474}

Hemos visto ya las mudanzas histórico-dialectales que ocurren en el territorio peninsular en los tiempos medievales. Hay un párrafo pidalino que sintetiza varias de esas mudanzas ocurridas en la trayectoria del idioma:

El leonés se dilata con las conquistas de Alfonso IX por Extremadura, Cáceres, Badajoz y Mérida (1227-1230). [...] El castellano arrincona al reino de León hacia el Occidente, [...] cuando Alfonso VIII repuebla a Plasencia (1189) y cuando el obispo de Plasencia toma a Trujillo (1232); igualmente el castellano estrecha al aragonés hacia el mar con la toma de Utiel y de Requena $(1219,1239)$; por el Sur, el castellano se ensancha con las conquistas de Fernando III en Andalucía (1225-1248) y Murcia (1241) (Menéndez Pidal, 2005, I, 490-491).

La unión de las respectivas Coronas de León y Castilla en 1230 contribuyó a la mezcla y posterior nivelación de sus dos dialectos, a lo que en términos más familiares se ha llamado su compenetración.

El asunto de la castellanización idiomática peninsular lo ha replanteado Inés Fernández-Ordóñez con manejo de Atlas y estudios -y por tanto de datos- que no pudo tener a su alcance Menéndez Pidal; nuestra autora se identifica más en el espíritu de su interpretación con García de Diego que con don Ramón, y va exponiendo:

a) «La fuerza expansiva alcanzada por el castellano es, en la perspectiva de Menéndez Pidal, una consecuencia del carácter irresistible de su literatura» (citamos siempre a Fernández-Ordóñez, 2011).

b) En lo que se refiere al diminutivo, «pese a la mayor implantación central de -illo, tanto medieval como moderna, parece claro que los sufijos preferidos en Castilla no han conseguido desterrar los de los territorios antes pertenecientes a los reinos de León y de Aragón, ni impedir que estos se extendieran por el sur peninsular».

c) Castilla posee -es necesario este párrafo extenso- dos primeras escisiones dialectales: «una que divide Castilla de norte a sur y que deslinda dos tipos de castellano: uno de tipo occidental, con rasgos comunes con el asturleonés, y otro de tipo oriental, con 
rasgos comunes con el área navarra (y aragonesa). [...] En ocasiones es el castellano de tipo occidental el extendido por el centro y sur de la península y en la lengua culta; otras veces, es el de tipo oriental. [... Estas dos clases de castellano] pueden ver interrumpida su difusión hacia el sur, bien en el Duero (y/o el Ebro), bien en el Tajo, bien en los márgenes de Andalucía»: estamos ante una segunda escisión dialectal que separa el Norte del centro y el Sur de la Península. «Mientras que el centro y el sur peninsular relajan, aspiran y pierden las consonantes en coda silábica, el Norte las mantiene incambiadas».

d) Muchos de los rasgos fonéticos que se estiman exclusivos del castellano «fueron también compartidos por los territorios vecinos del reino de León o de Navarra al menos; [...] rasgos supuestamente no castellanos se dieron o se dan» asimismo en Castilla.

e) «En ocasiones [...] las innovaciones lingüísticas parecen proceder del sur, y el norte tiende a conservar un estado lingüístico más antiguo», a saber: «zorra» / «raposa».

De esta manera y en conclusión, la irradiación de las diferentes soluciones idiomáticas de la lengua patrimonial arranca del Occidente peninsular, o del Oriente, o es navarro, o es cántabro-castellano pero no llega al Sur (leísmo, etc.) (Fernández-Ordóñez, 2011, 19; 26; 32; 36-37; 60-62; 88-89).

Los Atlas lingüísticos, más algunas monografías, hacen que pueda analizarse mejor que hasta ahora la complejidad constitutiva y dialectal de la lengua española.

Pero venimos ya a los tiempos que se inician tras 1454 en los periodos de la lengua castellana (1454-1492), época la segunda mitad de la cual es la que Menéndez Pidal estableció que arranca -según una distinta periodización- de 1474. Al llegar a esa fecha de 1474 en su Historia de la lengua española, don Ramón estima que se llega a «una nueva edad, la del español áureo o de los llamados siglos de oro, nuevo tipo de lengua y de literatura» (2005, I, 669). En efecto desde hacia fines del Cuatrocientos se llega a una nueva situación idiomática con la gran expansión del castellano -judíos expulsos, América-, y también las letras bellas resultarán distintas -Garcilaso, otros modos en la prosa, etc.-; el nuevo tipo fonético de lengua no ocurre realmente sino algo más tarde, en la segunda mitad del Quinientos, aunque ya en los decenios últimos del XV y en la primera mitad del XVI se renueva el habla común en Castilla la Vieja: este neologismo en lo fónico que aparece ya -según geografías- hacia la primera mitad del Quinientos es uno de los motivos por los que Pidal considera que estamos ante una «nueva edad del idioma» (Ibid., 875-876).

En todo caso, puede decirse que a esa lengua de una nueva edad es mejor identificarla en tanto la propia del siglo XVI y del siglo XVII que como «áurea», ya que el hablar ordinario no es nunca áureo: esta calificación estética puede aplicarse nada más que al idioma artístico de parte de tales centurias. Desde luego hace bien don Ramón en delimitar uno de los siglos aludidos del otro, ya que poseen consistencia diferenciada: el prof. José María Jover por ej. sitúa entre las fechas aproximadas 1480-1580 la cultura del Renacimiento en España, y entre las de 1580-1680 nuestra cultura del Barroco, y se trata desde luego de fases de lo histórico diferenciadas en su articulación sucesiva, como empezaron a ver quizá los primeros los estudiosos que tenían formación en Historia del Arte (Emilio Orozco, etc.); no creemos adecuada la idea de una edad renacentista de gran amplitud cronológica, tal como defiende aún Antonio García Berrio sin tener en cuenta -al parecer- cómo la mejor historiografía tiene bien establecido que Renacimiento y Barroco constituyen fases A y B de lo histórico, es decir, fases que contrastan respectivamente en cuanto expansiva y de depresión histórico-económica y social. 
Por otra parte cabe decir que según el análisis que hacemos, los años que van de 1474 a 1492 constituyen la segunda mitad de una época que podemos delimitar en la historia del idioma de entre 1454 y ese 1492, ya que los hechos nuevos y las rupturas se acumulan más bien en otra etapa, hacia la década última del siglo y los años posteriores; el propio Menéndez Pidal pensó en un primer momento $(1968 b, 48)$ en la relevancia de la fecha del 92, pero algo más tarde, al redactar la Historia de la lengua -e impulsado quizá (entre otras cosas) por su nacionalismo castellanista-, enfatiza más sobre la fecha de 1474 en que comienza el reinado de Isabel y cuando Fernando pasará pronto a ser monarca castellano efectivo (Vicens, 1944: 206a; cfr. Vicens, 1956: 236-240), e interpreta los datos en el sentido de que con Fernando e Isabel la comunidad política «alcanza su más alto punto de interna perfección y externo desarrollo»; de hecho el propio Jaume Vicens estimó que el hecho más significativo del reinado de los monarcas católicos fue el de «la conjunción de los dos [E]stados peninsulares más poderosos en un complejo político llamado a grandes empresas: el Estado español», y lo dijo con elocución acaso algo teñida por el momento $(1940,28)$.

Estamos por tanto ante una zona de fechas en las décadas finales del Cuatrocientos e inicios del Quinientos en que sucesivos hechos confluyentes determinan mucho la trayectoria de los idiomas peninsulares durante varias centurias: «el idioma sufre ahora en sus rumbos - manifestaba don Ramón- el giro más amplio y fuerte que en mil años de vida ha experimentado» (2005, I, 669). Don Ramón vivió antes que nosotros, pero como en nuestros días se sabe que las «Glosas Emilianenses» son posteriores a lo que se creía, cabe estimar con él que la lengua patrimonial tiene mil años -dicho desde luego de manera simplificadora, aproximada y para entendernos-, y que en efecto el giro más amplio experimentado en su historia externa es el que acaece hacia 1492, o sea -cabe añadir- hacia mitad de su trayectoria o realidad histórica; la segunda de las mitades es la del «español moderno» que más adelante tipificaremos. Y prosigue Menéndez Pidal (2005, I, 669-670): «El advenimiento de los Reyes Católicos unifica definitivamente los dos grandes dialectos afines, castellano y aragonés, que seguían caminos separados; hecho de tal importancia que necesitamos ascender al siglo XIII para hallar otro semejante en la unificación del castellano y el leonés bajo Alfonso el Sabio»; varias veces se ha recordado efectivamente que León parece castellanizarse en lo lingüístico de manera profunda desde 1230, y Aragón culmina análogo proceso en los años del reinado de su monarca Fernando II. Según la estimación pidalina, los varios dialectos peninsulares han concurrido para formar «el tipo lingüístico español» (2005, I, 695); es una idea compartida por el maestro y por el mencionado García de Diego, y lo que quiere decir es que el español es un complejo dialectal, que la lengua patrimonial ha incorporado en sí otros dialectos latinos de la Península.

En el Doscientos había ocurrido ciertamente - está señalado ya- que la unión ya definitiva de las coronas leonesa y castellana contribuyó a la más rápida mezcla y ulterior nivelación de los dos dialectos, de manera que

cuando se produce la conquista de Andalucía y Murcia [...] la repoblación del Sur se hace por gentes mezcladas de los dos reinos, sin separación entre gallegos, leoneses y castellanos, mezcla favorable a los influjos dialectales que integran la lengua común (2005, I, 490-491). 
Menéndez Pidal tenía por seguros los dialectalismos varios que se habían presentado ya en los códices regios de la General Estoria: llamer «lamer»; piedade (con vocal final no apocopada); interpolaciones entre el pronombre átono y el verbo («vos esta mi carta aduze»); ... (2005, I, 532-533). Y debe añadirse que en el tiempo que transcurre entre el rey Alfonso y hasta por lo menos Juan de Valdés (cerca de tres centurias) -es otra observación pidalina en un distinto escrito suyo $(1962,99)-$, se entiende que Toledo define el prototipo del castellano, ya que permanece una misma fonética: el español moderno surgirá con los cambios que se afirman según avanza el Quinientos. Cumplidos ya tales cambios quedará establecido en lo fónico el español «moderno», que en este sentido no debe llevarse -así lo creemos- hasta hacia 1700; tampoco resultan adecuadas las equívocas palabras de Fernando Lázaro cuando indica que en los tres primeros cuartos del siglo XV el idioma castellano fija cada vez más su perfil moderno $(1971,127)$ : el idioma tan latinizante de esas décadas no tiene nada que ver con lo que será fonética, sintácticamente, ese español de perfil moderno.

En el reinado de Fernando e Isabel se acumulan en coincidencia -venimos observando- diversos hechos que inciden muy decisivamente en la faz lingüística castellana. El cambio de orientación en el idioma literario lo ve representado Pidal en las Coplas de Jorge Manrique, en las que observa de manera particularmente ilustrativa:

Su lengua es aquella en que adquieren pleno valor poético las palabras más corrientes; es aquella en que cara, voz antes apenas usada, puede arrinconar a vulto y a viso, únicas expresiones nobles para los poetas de antes [...]. Si usa latinismos es con gran parsimonia: senectud va acompañado de los vocablos vulgares vejez y ancianía [... Da] elevación abstracta al lenguaje: sustantivación neutra (lo presente, lo no venido), infinitivo sustantivado (aquel trobar, aquel dançar, mi morir) (2005, I, 671-673).

Estos tres últimos casos -entre otros más- los tiene comentados asimismo Lapesa: los dos primeros (aquel trobar, aquel dançar) ejemplifican el uso de actualizador -en este caso un demostrativo- con infinitivo; por su lado «consiento en morir hubiera sido una manifestación [idiomática] formalmente normal; pero Jorge Manrique la enfatiza con un posesivo que pone más de relieve la personal asunción de la muerte por su padre, el Maestre don Rodrigo: «Y consiento en mi morir / con voluntad plazentera, / clara y pura»» (2000, caps. 24 y 25).

En tiempo de los Reyes Católicos -recordó Manuel García Blanco, para destacar la relevancia idiomático-literaria del momento- poetizaba Jorge Manrique, nació el teatro con Encina y se escribió La Celestina (García Blanco, 1967, 14).

\section{El Castellano literario en Cataluña}

El amplio giro en la situación idiomática del entonces dialecto castellano a fines del siglo XV consta de su llamada unificación con el dialecto aragonés, y además de otros hechos bien visibles, recordados por varios autores: obviamente los descubrimientos geográficos; y asimismo el conjunto de las empresas políticas exteriores; la expulsión y dispersión de los judíos y con ellos la historia del judeoespañol; el principio de una cierta uniformación de la lengua escrita que había traído la imprenta; la generalización del uso literario del castellano por autores de fuera de Castilla, en regiones geográficas 
en las que el vernáculo hablado era otro código (Portugal, Cataluña, etc.) (sobre el uso del castellano por los portugueses, A. Alonso1942).

Don Ramón simboliza asimismo -según queda visto- el giro experimentado por el castellano literario en los años siguientes a 1474 en las «Coplas» manriqueñas, ya que quebraban la estilística que había estado tan presente hasta entonces en la literatura más culta durante el Cuatrocientos: Jorge Manrique escribe en manera elegante pero no extravagante (de ruptura marcada con las normas del sistema); atrás empezaba a quedar el retoricismo que en realidad minusvaloraba el romance vernáculo, según le ocurrió a Juan de Mena, etc. La mentalidad renacentista avalora la lengua que nos es natural, frente al desprecio que en contra de ella acumuló el cultismo retoricista: «El Renacimiento ha de dignificar la lengua hablada [...que ] fue en seguida objeto de amor para los más egregios entre los renacentistas. Además la conciencia nacional buscó un punto de apoyo en las hablas locales frente al latín» que era internacional -expresó Américo Castro (1925, 195-196)-; no obstante de esa conciencia de lo propio no puede decirse que era sino protonacional, dada la centuria a la que nos estamos refiriendo.

El mismo Menéndez Pidal estampa -al venir refiriéndose a los años de los Reyes Católicos- una consideración que no debe tomarse tal cual; escribe así:

Si el olvido de la Edad Media y el gusto neológico hubieran proseguido desde tiempos de Santillana como prosiguió en Francia, el Poema del Cid sería tan incomprensible para el español de hoy como lo es la Chanson de Roland para un francés moderno. Pero el español fue en general menos evolutivo que el francés (2005, I, 689).

Efectivamente nuestra lengua patrimonial ha resultado menos evolucionada que el francés, pero el gusto neológico no explica por sí mismo el más alto grado evolutivo de la lengua francesa, ni explica que el texto al que él alude sea difícil para un francés de hoy.

En estos decenios en torno a 1500 de una nueva unificación entre los dialectos peninsulares históricos, el dialectalismo aragonés -según decimos- desaparece, y Aragón se convierte en centro de producción literaria en lengua española; por su parte el antiguo reino leonés aporta al español común -recuerda el hecho bien sabido don Ramón- el habla arcaica de sus aldeas como tipo de lengua villanesca en la literatura (Juan del Encina, Lucas Fernández): esa habla refleja literariamente los bables leoneses : «llugar»; «mudancia»; «obrigar»; ... (2005, I, 698 y 701). Yendo al teatro de Juan del Encina, encontramos efectivamente en sus piezas formas como «prazer», «perlabrado», «greja» «iglesia», «lle» «le», «ño» «no», «diabro», «San Pabro», «habro», «llabro» «labro», «empraziar» «emplazar», etc. (Encina1991: 98, 99, 195, 196, 221, 223, 224, 231).

Mejor que calificar en ocasiones de «corrupción» a la forma «greja» es hacerlo de dialectalismo estilizado poéticamente, lo que Amado Alonso llamaba un poco «prevaricación idiomática» en la literatura.

Sobre la situación idiomática peninsular Díaz Plaja $(1941,99)$ enunció con un acertado mirar que no siempre se encuentra, que «en Cataluña la lengua popular continuó siendo el catalán, pero el idioma de Castilla [...] fue utilizado por la mayoría de los escritores». Y cabe hacer referencia al cancionero llamado Jardinet d'orats que se acabó en 1486, el cual lleva veinte poesías en castellano, e incluye -al decir de Martín de Riqueruna muestra de importancia acerca de «la aceptación que comenzaba a tener la poesía 
castellana en Barcelona», una composición alegórico-cortesana en coplas castellanas -aunque tenga alguna mezcla de catalán-:

A suffrir penes aquí

havemos sobido dos:

Amor, por burlar de mí,

y yo para culpar a vos. [...]

Y todos serán ydos, sino uno;

soy quedado por benir

a quien deseo servir. [...] (Riquer, 1945, 31-37)

El presente filólogo comprueba también en las mismas páginas cómo en Cataluña ya antes de Boscán existía una tradición en el cultivo de la poesía castellana, de la misma manera que los portugueses que escribieron en lengua castellana, «entre los cuales y en conjunto hay figuras muy superiores» a las dadas por Cataluña a esas letras castellanas.

En efecto Martín de Riquer se ha referido en sucesivas ocasiones a lo largo de los años a la llamada decadencia de las letras catalanas que se estima en algunas interpretaciones que va de primeros del XVI a mitad del XIX, en los cuales «se reduce hasta casi su desaparición el cultivo del catalán como lengua literaria culta».

En la estimación de este crítico, durante los siglos XVI, XVII y XVIII no se escribe en catalán obra en prosa de cierto alcance literario; la poesía en cambio logra mantenerse con dignidad. (Riquer, 1947, 137-151).

La estimación a su vez de Rafael Lapesa es la de que

durante el siglo XVIII y buena parte del XIX continuó, agravada, la decadencia del catalán; fuera de la conversación familiar y la predicación, contaba por únicas manifestaciones libros piadosos y coplas callejeras; aún más completa era la postración del gallego, [... pero] las regiones bilingües dieron valiosas figuras a la literatura nacional [... Con el Romanticismo] la elaboración literaria del catalán, la menos sostenida y menos extensa del gallego, y los intentos de capacitar al vascuence como lengua de cultura, no impidieron que continuara la aportación de las respectivas regiones a la literatura [...] en castellano (1981, § 115).

Este mismo autor se ha mostrado siempre sensible ante el plurilingüismo peninsular y así no ha dejado de volver al asunto; señala por igual que «las primeras generaciones del resurgimiento literario catalán no manifiestan rencor antiespañol», aunque con posterioridad «no es menos cierto que tanto el auge del separatismo excluyente como la torpeza del poder central durante las dos dictaduras [de los generales Primo de Rivera y Francisco Franco], han contribuido a plantear la tensa, verdadera crisis lingüística de la Cataluña actual» (1996a, 64-65); Antoni Badía ha comentado con respetuosas y parciales discrepancias estas u otras análogas percepciones de Lapesa, y resulta necesario tener también presentes sus párrafos (1997, 1-2).

A partir de hacia el Quinientos surgió en efecto la cuestión de la que se ha llamado convivencia entre catalán y castellano (sobre el asunto hay una conferencia y un artículo de F. Lázaro, 1999; 2002, esbozo de un libro que debiera escribirse).

En síntesis en el tiempo de los Reyes Católicos en las regiones en las que no era idioma hablado, el castellano se adoptó en cierta medida como lengua literaria. 
LA LENGUA ESPAÑOLA COMO CONTINUIDAD ININTERRUMPIDA EN LA QUE SE PRODUCEN DISCONTINUIDADES

La nueva edad idiomática distinguida analíticamente por Menéndez Pidal no significa que hubiese una ruptura tal en el hablar, que las gentes se hubieran dejado de entender: un castellanohablante que vivió de 1470 a 1530 se comunicó de seguro con personas mayores en edad que él y asimismo con otras menores, pues la lengua presenta discontinuidades ciertamente, pero es un continuo de gran densidad tradicional, y por eso las innovaciones se implantan de modo tan lento. Las generaciones biológicas se suceden unas a otras y no dejan de comunicarse mediante una lengua que evoluciona pero no experimenta una ruptura sino en espacios de tiempo multiseculares: así el latín acabó por hacerse ininteligible.

Nadie como el propio Ramón Menéndez Pidal supo razonar esta relativa inmutabilidad de las lenguas, al establecer una tipología de los productos lingüístico-literarios tradicionales que no acostumbra a recordarse, pero que resulta de gran lucidez. En un Discurso de 1944 ponía en paralelo «la canción popular y tradicional» y el lenguaje, para advertir en ambas actividades la participación en libertad del individuo; debemos traer a colación pasajes suyos algo amplios, pero que resultan necesarios para saber entender bien al autor:

Cada recitador de un romance o balada en tensión poética o creadora -explica-introduce variantes en el texto que recita; jamás un romance se repite exactamente de igual modo sino con variaciones individuales, aunque sin embargo a pesar de tantas modificaciones el texto tradicional se conserva sin esencial alteración [...] Y lo mismo cabe decir del lenguaje: la lengua está en variedad continua y en permanencia esencial. Cada hablante moldea los materiales que en su memoria ha depositado la tradición, los transforma ajustándolos al estímulo expresivo que le mueve a hablar, los vivifica dándoles una existencia singular que nunca tuvieron antes ni volverán a tener después jamás; pero a pesar de eso, la lengua permanece en su identidad esencial, pues el individuo crea su habla en continuo ajuste y contraste con la comprensión del oyente y con el uso general de los demás hablantes (1944, 193-194).

El lenguaje -es decir- cada lengua histórica, la castellana y más tarde española en nuestro caso, permanece en su identidad fundamental a lo largo de su milenario aproximado de existencia: se dan en su trayectoria transiciones, haces de isoglosas, no rupturas bruscas, pues unos hablantes tras otros nunca han dejado de entenderse en lo inmediato.

El recitador de romances y lo mismo un hablante cualquiera pueden resultar innovadores, aunque en el caso del lenguaje el acomodo al uso general de los demás hablantes, el espesor de resistencias que se oponen a una innovación que resulte extraña e incluso que parezca un poco extravagante, etc., limitan el posible impulso innovador; en todo caso la variación y -si llega a ocurrir- el cambio lingüísticos proceden de la iniciativa individual que encuentra eco en los demás hablantes y ellos la adoptan y hacen suya hasta conseguir una generalización y nivelación idiomáticas. Don Ramón lo plantea así:

Es evidente que los cambios que se produzcan en el lenguaje, siendo éste un hecho humano, serán siempre debidos a la iniciativa de un hombre, de un individuo que al desviarse de lo habitual logra la adhesión o imitación de otros, y éstos logran la de otros; en suma, el proceso de cualquier neologismo será idéntico al proceso por el que se propaga cualquier opinión o 
cualquier costumbre en un grupo humano, hasta hacerse propia de la mayoría [..., ] así que un individuo puede influir poderosamente en el lenguaje de la comunidad hablante (1944, 194-195).

Cualquier variación idiomática procede de un punto de partida o de un empeño consciente individual, y no se llega al cambio si tal variación no se difunde en la comunidad hablante y su uso se generaliza y se asienta. Extraña así que parezca afirmarse que el sistema resulta ajeno a las innovaciones que se producen en el hablar: M. Alvar mantiene que «la vida afecta a la realización del sistema, no a su estructura, que permaneces ajena a la vida» $(1982,42)$; sin embargo son las realizaciones del sistema las que inciden muy lentamente en su estructura y pueden cambiarla.

A su vez este maestro asturiano (don Ramón) de raigambre y vinculado así en su propia vida a un habla dialectal, volvió a referirse con más decisión a los presentes asuntos en las páginas que añadió a la última edición que hizo de su bello libro Poesía juglaresca y juglares, ahora cambiado de título; digamos antes -ya que es instructivo para nuestros propósitos- que Amado Alonso reseñó la primera edición de esta Poesía juglaresca ... (1926): advirtió la renovación y precisión que introducía don Ramón en algunos de los conceptos de que hace uso la Historia literaria, y aprobaba asimismo la traza histórico-cultural que ha de tener (al par de la Historia idiomática) la Historia literaria, y destacó de esta forma cómo «el Sr. Menéndez Pidal sorprende el nacimiento de nuestra literatura [...] de las entrañas vitales del pueblo español. [...] El estudio de la literatura y la evocación de la vida nacional que la produjo y le sirvió de marco se cumplen aquí, en maravillosa unión orgánica». Desde luego hay una unicidad de método al historiar la lengua y la literatura según lo hace Menéndez Pidal: se trata de ver el idioma y las producciones poéticas tradicionales en su hacerse tanto individual como social y colectivamente.

Llama entonces Menéndez Pidal (1957) al sacar su Poesía juglaresca y orígenes de las literaturas románicas, «primer grado» de tradicionalidad a la del lenguaje, sin duda -no lo aclara de manera completamente explícita- por tratarse de una actividad sumamente tradicional ya que intervenimos todos en ella; «primer grado» quiere decir ahora (debe aclararse) grado más alto, mayor densidad tradicional.

En primer término vuelve a postular don Ramón el origen individual de toda innovación que se produzca en la materia tradicional, y de esta manera expone:

El menor cambio que en la tradición se observe fué originariamente introducido por un individuo innovador, cuya innovación tuvo influjo prestigioso bastante para ser imitada por otro y otros, hasta hacerse general [...]. Pero ocurre que cuanto más extenso es el campo en que la tradición actúa, [...] la participación de cada individuo en la trasmisión no se disminuye, pero la eficiencia de esas alteraciones individuales, sí, es mucho menor, porque la innovación individual tropieza con la resistencia de muchos más individuos que se mantienen fieles al patrón común heredado por todos $(1957,365)$.

Se trata de que ciertamente en toda actividad tradicional la innovación -según sabemos- es siempre individual, y su generalización sólo se produce por el prestigio que la hace difundirse: en el caso del lenguaje tal prestigio puede residir en que una designación resulte bella, ingeniosa, expresiva, etc., o bien en que sea una forma propia de un escritor autorizado, ...; no obstante si una tradición se halla socialmente muy implantada y extendida (y así ocurre con el lenguaje), cualquier innovación que se haga en la misma por lógica hallará más obstáculos para asentarse e imponerse, y cabe así distinguir grados de 
tradicionalidad. El lenguaje es el hecho más tradicional, puesto que la sociedad entera participa de él y su tradición actúa sobre todos los miembros de una comunidad.

Don Ramón atiende enseguida de manera particular al idioma en tanto tradición -según vemos- en grado muy alto, y entonces razona otra vez:

La historia del lenguaje, que es tradición en la que intervienen absolutamente todos los individuos que componen el cuerpo social, alcanza tal fijeza y tal regularidad en sus lentos cambios que parece estar regida por leyes independientes de la voluntad humana [...]. La constitución y evolución del lenguaje no es acto extraño a la voluntad e inteligencia del individuo; el más pequeño cambio evolutivo del lenguaje procede siempre de la voluntad consciente o semiconsciente de un individuo innovador, de la inteligencia acertada o errónea, de la sensibilidad o imaginación de un individuo que en su habla conforma o deforma a su gusto, a su manera, la pronunciación, el vocabulario o la fraseología de la lengua materna aprendida $(1957,365-366)$.

Menéndez Pidal se hace cargo en el total de su párrafo de Saussure, y describe luego el proceso que no menciona el maestro de Ginebra: el de la aceptación por sucesivos hablantes de una innovación hasta generalizarse y pasar a ser sistemática. Nuestro autor asiente por supuesto - pues era su propia idea- a que nada llega al sistema de la lengua si antes no ha estado en el habla, pero precisa que el hablante innovador ha de captarse adhesiones, y que la propaganda lingüística -lo repite- se logra mediante la enseñanza, los diccionarios, etc. $(1957,366)$.

Además insiste también don Ramón en que el romance es ejemplo de «un segundo grado en cuanto a la extensión del campo tradicional», y ocurre que el romance «vive en variantes, porque cada uno que lo canta lo considera como cosa propia», aunque en definitiva «el romance goza de grande aunque relativa estabilidad» $(1957,367)$.

En la lengua y en el romancero un individuo lleva en cada caso la iniciativa de la innovación, y si tal novedad adquiere prestigio y es seguida por los demás hablantes o recitadores, se integra y estabiliza en cuanto cambio en el idioma o en el texto romanceril. Un rasgo característico además de los productos tradicionales como el lenguaje es que uno de sus fenómenos - un cambio consonántico, digamos- puede haber empezado a existir y sin embargo no aparece a nuestros ojos: se encuentra entonces en estado latente: así el latín vulgar que por evolución dio lugar a las lenguas neolatinas «vivió siempre en estado latente cinco o seis siglos, sin que nadie jamás pensase en escribirlo» (Menéndez Pidal, 1963,129-130; vid. 1950, §112.2.).

Sabemos pues que las lenguas humanas tienen gran tradicionalidad, que el cambio en ellas puede ser multisecular, que las generaciones de hablantes se suceden unas a otras sin que se produzca ininteligibilidad entre sí: las aclaraciones e ilustraciones expuestas por Menéndez Pidal y olvidadas hoy quizá entre las muchas páginas escritas por él, resultaron sobremanera instructivas y por eso las hemos recogido (sobre la tradición de romances en América -junto a la de la lengua-, Menéndez Pidal, 1958, 13-87). Llama la atención que Amando de Miguel y Francisco Marcos apunten que existió una solución de continuidad, una ruptura, entre el castellano medieval y el castellano moderno: el segundo de ellos ha escrito decididamente que «el sistema del castellano medieval era tan diferente del actual que no sería ninguna barbaridad considerarlo una lengua distinta» (Marcos 2008, 58); de manera conjunta, ambos autores manifiestan que «castellano 
se refiere a un sistema que llega al siglo xv y español al que empieza entonces» (de Miguel- Marcos, 121), o sea, que no es que estemos ante dos nombres de una misma realidad, sino ante realidades contrapuestas, ante dos «sistemas» idiomáticos.

Pero esta postura de que castellano de la Edad Media y español de los tiempos modernos constituyen idiomas distintos ningún filólogo (que sepamos) la ha mantenido, ni recibirá quizá muchas adhesiones; de hecho y por ejemplo, Juan Miguel Lope Blanch ilustró y probó con muchos análisis sintácticos diacrónicos y dialectales que hizo (y se deduce de ellos), que la lengua desde hacia finales del siglo XII -que es desde cuando se conservan textos enteros suyos- resulta estructuralmente unitaria en lo fundamental y es por tanto una misma lengua, aunque en unas etapas hiciese uso de un mayor número de oraciones sintácticamente distintas y en otras etapas de otro menor; en lo fónico a su vez, la ruptura con lo medieval que se generaliza no ocurre sino en la segunda mitad del siglo XVI e inicios del XVII. Un hablante de hacia 1479 no dejaría de entenderse con otro de 1516, ni uno de 1492 con otro de 1527; en la historia del castellano no hay discontinuidad absoluta, ni ruptura en la comunicación y por tanto en la comprensión lingüística mutua: la llamada doña Juana la Loca lo mismo podría hablar con sus padres los Reyes Católicos que con sus hijos que se expresasen en castellano.

$\mathrm{Si}$ vale el argumento de autoridad, diremos que ninguno de los estudiosos que sucesivamente han conocido mejor quizá la lengua del siglo XVI (Menéndez Pidal, Amado Alonso, etc. ), ha advertido nunca algo que lleve a postular un español estructuralmente distinto tras el 1500 de un castellano medieval anterior. Menéndez Pidal trata-según está dicho- de una «época de Nebrija» en la historia de nuestra lengua (1492-1525) y sin que se produzca solución de continuidad de otro «período de Garcilaso» (1525-1554) (1968b, 48-73): ninguna referencia encontramos en él de que se haya producido un cambio estructural en el idioma; de igual modo Manuel García Blanco tampoco hace alusión alguna a esa supuesta ruptura entre sistemas distintos que se suceden el uno al otro (1967), porque realmente no hay pruebas de que así ocurriera.

\section{EL XVI COMO EL GRAN SIGLO: RAZONES DE ESA ESTIMACIÓN}

De manera acaso no siempre expresa en Menéndez Pidal y más explícita en Amado Alonso, el siglo XVI se ha tenido por el gran siglo español en materia de lenguaje, el de mayor logro idiomático en los escritores y el de gran trascendencia por el trasplante de la lengua a América. Desde luego la historiografía general habla solventemente en relación con el Quinientos -y en nuestros días- de «el siglo de España», y establece que «la potencia que encabezó la expansión exterior de Europa y que generó el conflicto en el interior de Europa fue España, ofreciéndonos España un epicentro geográfico para el siglo» (Mackenney, 1996, 32).

Acaso por incluir el denominado año admirable 1492 en esta estimación de lo áureo del Quinientos, don Ramón inició un primer análisis de «el lenguaje del siglo XvI» por los años 1492-1525, momento al que llama -según está dicho- «época de Nebrija» (1968b, 48-62; el segundo de sus análisis es el incluido en la «Parte quinta» de 2005, I). No debe quedar inadvertido que Menéndez Pidal empezó a redactar y anticipar su Historia de la lengua española por este artículo aludido acerca del lenguaje del XvI, quizá 
como prueba de estimación hacia ese momento hitórico, lingüístico y literario español; luego al redactar la obra extensa Historia ...., redactó de nuevo todo e incluso introdujo cambios que no advierte: sólo quien no haya leído ambas exposiciones del mismo asunto puede pensar que la primera de los años treinta no tiene vigencia y debe olvidarse.

La estimación por la historia española del XVI que tuvo Menéndez Pidal puede verse por ej. en que escribió acerca de Carlos V y del P. Las Casas, y en que en tal contexto y tratando de las cosas de América, se inclina según una historiografía romántica enaltecedora de los héroes, por las «ilustres hazañas» de los conquistadores más que por su «codicia insaciable»; seguramente quizá el noventayochismo pidalino y su amor a las cosas patrias entendido de una determinada manera, es el que le hace dolerse tanto con Las Casas hasta haberle dedicado un libro entero que no en todo resultó afortunado (cfr. las «páginas sobre la España imperial» de Menéndez Pidal, 1973, esp. 232-269). En la traza de su maestro don Ramón, asimismo Manuel García Blanco se ocupó del idioma del XVI, y veía por igual «la perfección y madurez» de la centuria en su segunda mitad $(1967,43)$ : sin duda es una concreta mentalidad la que lleva a notar mucho la nacionalización que -se interpreta- ocurre en los tiempos de Felipe II con el arraigo nunca alcanzado antes de la lengua castellana, etc.

Amado Alonso, que se había formado en la escuela pidalina y luego asimismo en Alemania, hereda quizá de la escuela el gusto por el Quinientos frente al Seiscientos, y parece rechazar a sus maestros alemanes en su reivindicación del Barroco; dice así en un párrafo escrito a mitad de los años cuarenta (1967, 8-9): «La mayoría de los hispanistas hasta hace poco veían la sazón del clasicismo en el siglo XVII, en el genial Cervantes anciano y, sobre todo, en el esplendor barroco presidido por Calderón. El siglo XVI era una magnífica antesala», aunque no obstante en ella encontramos a Jorge Manrique, a Fernando de Rojas, Garcilaso, Guevara, ...: «el idioma de Guevara y de Garcilaso resulta más cercano a nuestro actual sentimiento lingüístico que el de Calderón, Quevedo y Góngora». Un don Amado coetáneo y amigo de los hombres del 27 pero alejado de ellos en su estancia argentina, quizá no estimaba los valores idiomáticos de un Luis de Góngora, y en años de madurez vuelve a su fomación inicial pidalina y a sus estimaciones.

Según decimos, el escrito breve pidalino acerca del lenguaje quinientista tiene apreciaciones vigentes y sugestivas. Para empezar, propone que la amplia duración de un siglo se subdivida en el transcurrir temporal de una lengua: se trata así de indicar «una periodización más corta que el siglo, una estimación más precisa del factor temporal, que nos pueda encaminar hacia individualidades históricas más reales» (Menéndez Pidal, 1968b, 48). Efectivamente lo histórico no es genérico sino específico, y la cronología de la evolución lingüística, la creación idiomático-literaria de los grandes autores, etc., da lugar a una configuración de cada periodo histórico en la trayectoria del idioma que es -al buen decir de Pidal- una individualidad histórica real.

Ya queda repetido que don Ramón delimita en el lenguaje que él denomina quinientista una «época de Nebrija» desde «los últimos años del siglo anterior» (entiéndase «1492»), hasta «hacia 1525», y destaca en tanto lo inicial la gran innovación nebrisense de escribir una gramática de una de las lenguas romances; no obstante incurre en una manifestación tópica que no cabe sostener, y es la de que esa Gramática «fué escrita en esperanza cierta del Nuevo Mundo», esperanza que nunca existió, ya que Antonio alude a pueblos bárbaros de peregrinas lenguas a quienes se sometería que de ninguna manera (estábamos años an- 
tes del 92) eran los amerindios: «una idea renacentista -estima Pidal- impulsa a Nebrija: España sueña con un imperio como el romano, y el español se iguala al latín. Nebrija [...] acomete su innovación para fijar el idioma» (1968b, 49); esa mentalidad imperial que interpreta con énfasis el filólogo responde quizá a una exaltación nacionalista que él hace.

La Gramática sobre la lengua castellana -este es el verdadero título, según defendimos ya por escrito hace treinta años- de Nebrija evoca en la misma interpretación pidalina las ideas «de fijación del idioma y expansión del mismo», cosa que es así si no entendemos que tal expansión en que pensaba Antonio era la americana; la fijación tiene que ver con la análoga dignidad que se concede al castellano respecto del latín.

En la misma traza pidalina de estimación hacia el Quinientos, Guillermo Díaz Plaja ha mostrado algunas realidades de la lengua peninsular en la centuria:

Fray Antonio de Guevara imita las formas clásicas latinas, incluso las parejas de sinónimos que repite constantemente para exhibir la riqueza de su léxico, pero sin caer en la extravagancia ni en lo dificultoso. Este momento [de la primera mitad del siglo XvI] viene marcado por un lenguaje equilibrado entre lo culto y lo popular, en un discreto término medio característico del momento, que se estudia con el nombre de buen gusto $(1941,99)$.

La estimación filológica del Quinientos ha tenido verosímilmente como uno de sus principales motivos la que por la centuria sintió y con su autoridad indujo Menéndez Pidal, autor en quien esa avaloración dependió por supuesto de la importancia del momento en la historia de la lengua, pero algo asimismo de la propia mentalidad del autor exaltadora de un pasado avalorado como superior.

\section{REFERENCIAS BIBLIOGRÁFICAS}

Alatorre, Antonio (1989): Los 1,000 años de la lengua española, ed. aumentada, México, FCE. Alonso, Amado (1926): reseña a R. Menéndez Pidal, «Poesía juglaresca y juglares», Revista de la Biblioteca, Archivo y Museo [del Ayuntamiento de Madrid], III, 1926, pp. 377-380.

- (1942 ): reseña a Gil Vicente, «Tragicomedia de Don Duardos» editada por Dámaso Alonso, $R F H$, IV, pp. 282-285.

- (1967): Estudios lingüísticos. Temas hispanoamericanos, tercera ed., Madrid, Gredos.

Alvar, M. (1982) [el Depósito Legal es de 1983]: La lengua como libertad, Madrid, Eds. Cultura Hispánica.

Badia Margarit, A. (1997): «La lengua española: ¿triunfos o trances?», Saber leer, n. ${ }^{\circ}$ 107, pp. 1-2.

BALDINGER, K. (1977): «Consideraciones sobre el desarrollo y sobre las perspectivas de la lingüística», Lexis, 1, pp. 1-4, más un gráfico en página 2A.

- (1985): «Lengua y cultura: su relación en la lingüística histórica», RSEL, 15/2, 1985, pp. 247-276.

Castro, Américo (1925): El pensamiento de Cervantes, Madrid, Centro de Estudios Históricos.

- (1948): España en su historia. Cristianos, moros y judíos, Buenos Aires, Losada.

Coseriu, E. (1981): Lecciones de lingüística general, Madrid, Gredos.

Díaz Plaja, Guillermo ([1941]): Historia del español, Barcelona, Eds. La Espiga.

Encina, Juan del (1991): Teatro completo, ed. de Miguel Ángel Pérez Priego, Madrid, Cátedra.

FERnÁNDEZ ORdóÑEz, Inés (2011): La lengua de Castilla y la formación del español, Madrid, RAE.

García Blanco, Manuel (1967): La lengua española en la época de Carlos V y otras cuestiones de lingüística y filología, Madrid, Escelicer. 
García Isasti, Prudencio (2004): La España metafísica. Lectura crítica del pensamiento de Ramón Menéndez Pidal (1891-1936), Bilbao, Real Academia de la Lengua Vasca.

Ladero Quesada, Miguel Ángel (1998): Lecturas sobre la España histórica, Madrid, Real Academia de la Historia.

LAPESA, R. (19819): Historia de la lengua española, Madrid, Gredos.

- (1996a): Crisis [ «cambios importantes»] históricas y crisis de la lengua española, Madrid, RAH.

- (2000): Estudios de morfosintaxis histórica del español, Madrid, Gredos.

LÁzaro Carreter, Fernando (1971): Lengua Española: Historia, Teoría y Práctica, I, Salamanca, Anaya.

- (1999):El nacionalismo lingüístico catalán: orígenes, Madrid, Fundación Ramón Areces.

- (2002): «En los comienzos de una convivencia», en el volumen colectivo Un siglo de España, Madrid, Alianza, pp. 165-172.

Mackenney, ( 1996): La Europa del siglo XVI, Madrid, Akal.

Maravall, José Antonio (1983a): «Del régimen feudal al régimen corporativo en el pensamiento de Alfonso X», recogido en sus Estudios de historia del pensamiento español. Serie Primera, pp. 97-145.

- (1983b): «El problema del feudalismo y el feudalismo en España», recogido en sus Estudios de historia del pensamiento español. Serie Primera, pp. 423-435.

Maravall, J. A. (1983c): Estudios de historia del pensamiento español. Serie Primera. Edad Media, tercera ed. ampliada, Madrid, Eds. Cultura Hispánica, 1983.

Marcos, Francisco (2008): «El español y cómo llegó a serlo», Revista de Occidente, n. ${ }^{\circ} 320$, Enero 2008, pp. 53-83.

Márquez Villanueva, Francisco (1994): El concepto cultural alfonsí, Madrid, Mapfre.

Menéndez Pidal, R. (1943): «Carácter originario de Castilla», incorporado a Castilla. La tradición, el idioma, pp. 9-39.

- (1944): «La unidad del idioma», recogido en Castilla. La tradición, el idioma, pp. 169-215.

- (1945 y reimpresiones sucesivas): Castilla. La tradición, el idioma, Buenos Aires, EspasaCalpe.

- $\left(1950^{3}\right)$ : Orígenes del español, Madrid, Espasa-Calpe.

- (1957): Poesía juglaresca y orígenes de las literaturas románicas, Madrid, Instituto de Estudios Políticos.

- (19586): Los romances de América y otros estudios, Madrid, Espasa-Calpe.

- (1962): «Sevilla frente a Madrid. Algunas precisiones sobre el español de América», en la Miscelánea Homenaje a André Martinet, III, Universidad de La Laguna, pp. 99-165.

- (1963a): «El estado latente en la vida tradicional», Revista de Occidente, nueva época, n. ${ }^{\circ} 2$, pp. 129-152.

- (1968²a) [1956]: España, eslabón entre la Cristiandad y el Islam, Madrid, Espasa-Calpe.

- (19685b) [1942]: La lengua de Cristóbal Colón. El estilo de Santa Teresa y otros estudios sobre el siglo XVI, Madrid, Espasa-Calpe.

- (1973) [1957]: Mis páginas preferidas. Temas lingüísticos e históricos, Madrid, Gredos (reimpr.).

- (2005): Historia de la lengua española, vols. I y II, Madrid, Fundación Ramón Menéndez Pidal y Real Academia Española.

de Miguel, Amando, y Marcos, Francisco (2009): Se habla español. Madrid, Biblioteca Nueva y Fundación Rafael del Pino.

PenNy, Ralph (1995): «Sobre el concepto del castellano como dialecto «revolucionario», en las Actas del I Congreso de Historia de la lengua española en América y España, Universitat de València, pp. 403-407. 
Pérez Moreda, Vicente (1988): «La población española», en M. Artola, ed., Enciclopedia de Historia de España.1. Economía. Sociedad, Madrid, Alianza, pp. 345-431.

Pérez Prendes, José Manuel (1984): «Derecho y Poder», en la Historia General de España y de América. IV. La España de los cinco reinos (1085-1369), Madrid, Rialp, pp. 3-83.

RiQuer, Martín de (1945): Juan Boscán y su cancionero barcelonés, Ayuntamiento de Barcelona.

- (1947): Resumen de literatura catalana, Barcelona, Seix Barral.

Riv Riv, Manuel (1984): «Sociedad y Economía», capítulo de la Historia General de España y América, IV, Madrid, Rialp, pp. 85-178.

SÁnchez Albornoz, Claudio (1943): «Orígenes de Castilla. Cómo nace un pueblo», Revista de la Universidad de Buenos Aires, I/2, pp. 275-296.

- (1983) [1956]: España,un enigma histórico, Barcelona, Edhasa.

- (1979) [1958], Los reinos cristianos españoles hasta el descubrimiento de América, Buenos Aires, Depalma.

- (19812) [1974]: El Islam de España y el Occidente, Madrid, Espasa-Calpe.

Vicens Vives, Jaime (1940): Política del Rey Católico en Cataluña, Barcelona, Destino.

- (1944): Mil figuras de la historia, II, Barcelona, Gallach.

- (1956): Els Trastàmares, Barcelona, Ed. Vicens-Vives. 